Jurnal Keperawatan Padjadjaran

ISSN 2338-5324 (print)

ISSN 2442-7276 (online)

Online di http://jkp.fkep.unpad.ac.id

DOI : $10.24198 / \mathrm{jkp}$

\title{
The Effectiveness of Dhikr to Intensity of Pain during Active Phase in Mothers Getting Inducing Labour
}

\author{
Nurhidayatul Mualimah, Irma Nurbaeti*, Puspita Palupi \\ Faculty of Health Sciences, Universitas Islam Negeri Syarif Hidayatullah, Jakarta, Indonesia \\ Corresponding email: irma.nurbaeti@uinjkt.ac.id
}

Submitted: 26-07-2020 Accepted: 30-08-2020 Published: 31-08-2020

\begin{abstract}
Women in labor process with induction are more painful than normal labor that need to applicate an intervention to reduce pain in stage I labor. The purpose of this study is to determine the effect of dhikr towards intensity of pain of labor during the active phase of the mother with labour induction. The study was conducted since May until June 2018 with one group quasi-experimental design. Pain score is measured before and after dhikr using Visual Analog Scale (VAS) every 30 minutes during the active phase of first stage. The mothers who met criteria recruited as the samples. Fifteen muslim mothers who had first labor induction, starting cervical dilatation in $4 \mathrm{~cm}$, gynecoid pelvis and completed cervical dilatation to $10 \mathrm{~cm}$. Statistic analysis performed by ANOVA Repeated Measure test at $\alpha=0.05$. The result of the statistical test shows that dhikr has moderate effect of $32.5 \%$ to decrease the average score of induction pain at the active phase of first stage (value-p=0.08) after controlled with confounding variables; age and parity. Dhikr had an effect on the decrease of VAS score after 30 minutes intervention ( $p$-value $=0.016)$, but did not affect the measurement at the end of the first stage of labour ( $\mathrm{p}$-value $=0.651)$. Therefore, dhikr could be used to control pain of induced labor during active phase of first stage. Suggested has teached pregnant women since the third trimester and combined with the other intervention to reduce labour pain.
\end{abstract}

Keywords: Dhikr, induction labor, nursing, pain. 


\section{Introduction}

Labor induction is a process of achieving vaginal delivery by stimulating uterine contractions before the onset of spontaneous labor (Goodwin, 2010). Increased frequency of uterine contractions that occur in mothers with labor induction can increase labor pain in the first stage, because strong contractions are a strong source of pain (Andarmoyo, 2013). Rahmawati (2014) stated that the pain of the first stage of labor in mothers with induction of labor was stronger than that of normal delivery mothers. In addition, drip or injection of induction of labor happens rapidly that the brain can't respond properly to pain in the early stage. Labor induction had been associated with potential risks, such as uterine tachysystole with or without fetal heart rate changes that resulting more contraction of uterine which consequency is mothers feeling more painful (Viteri and Sibai, 2018).

Pain the the First stage of labor varies in accordance with the phase. The first stage of labor consists of 2 phases, namely the latent phase (cervical opening 1-3 cm), the active phase $(4-10 \mathrm{~cm})$. Women begin to feel uncomfortable when entering the active phase, because the intensity of contractions begins to increase, longer. The active phase is the most appropriate phase for mothers to do relaxation techniques. (Cuningham, 2016; Rici, 2013). Women can reduce pain in stage I labor by reducing pain intensity and reduce pain sensation with relaxation therapy (Manning, 2013).

Labor pain that is not handled properly can have a bad impact. Labor pain can have a psychological impact on the mother, i.e. anxiety. Anxiety that is felt by someone can increase the secretion of adrenaline as a result of the body's response to psychological stress and hypoxia associated with labor pain. Increased adrenal secretion can cause vasoconstriction as a result of decreased uterine blood flow, resulting in the occurrence of fetal hypoxia and bradycardia which will eventually occur fetal death and can inhibit contractions, thus slowing labor (Saragih, 2017).

Duration of labor is one of the causes of maternal death, so indirectly pain in labor if not getting adequate intervention can cause maternal death. Therefore, labor pain is something that should be a concern for birth attendants, including nurses. According to the Dick-Read theory, women can reduce their pain by reducing pain intensity and reducing pain sensation with relaxation therapy (Manning, 2013). Previous studies exhibited the factors that most influenced labor pain were previous experiences of labor pain associated with parity, age (Meštrović et al., 2015; Shrestha et al., 2013; Tampubolon, 2015).

Relaxation therapy is a form of nonpharmacological to reduce pain. For Moeslim patients, one of selected choice of relaxation therapy during stage I labor process is dhikr. Dhikr is a relaxation technique that can activate God Spot, the center of religiosity in the brain. It can be stimulating hypothalamus to activate the work of the parasympathetic nervous system and increase endorphin secretion. Gate control theory explains improvement Endorphin secretion can inhibit delta-A and $\mathrm{C}$ neurons from inhibiting release of substance $\mathrm{P}$ thereby closing the defense mechanism (door gate). When the gate is closed, the message is conveyed to cerebral cortex in the form of modulation stimulation, not pain. Remembrance is a form of worship by remembering and reciting Asma Allah repeatedly (Yusuf, 2017).

Some researchs by Nurbaeti (2015), Fajriah (2013), and Sumaryani (2015) showed that dhikr had an effect on the average decrease in the intensity of first-stage labor pain in primipara. Some study the effect of dhikr on the pain in spontaneous labor had been conducted, but a little study the effectiveness of dhikr on pain intensity among inducing labour. However, nowaday, increasing rate of use of labor induction and labor pain stronger than spontaneous labor pain (Goodwin, 2010; Rahmawati, 2014). Important to know effectiveness dhikr on pain during active phase encourage to conduct research. The purpose of this study was to analyze the effectiveness dhikr on the intensity of labor in active phase of labor in inducing mother.

\section{Method}

Research design is one group quasi experimental design. Labour mothers who met the criteria were recruited in month of May to June 2018. Inclusion criteria were

Volume 8 Issue 2 August 2020 
Irma Nurbaeti: The Effectiveness of Dhikr to Intensity of Pain during Active Phase

moeslim women, in the active phase with $4-7 \mathrm{~cm}$ opening, first getting induction, normal pelvis (pelvic gynecoid) and had completed cervical dilatation till $10 \mathrm{~cm}$. Exclusion criteria were maternal women who experienced induction failure or received pharmacological analgesic therapy and had fetal distress. From 29 mothers, 14 mothers drop-out cause of failed induction, getting Sectio cesarian birth and had fetal distress. A number of 15 mothers completed the intervention and measurement.

Selected participants who met criteria and agreed to participated in this study were explained about procedure of intervention. Before intervention, researcher collected demographic characteristics and measure pain scale. The procedure of intervention of dhikr had been done every 15 minutes since the first cervical dilatation of four. Initial mothers guided dhikr by researcher, and repeated every 15 minutes. Mothers also were provided guidance of dhikr.

The instruments consisted of demographic characteristic consist of ethnic, level of education, working status, obstetric status and labor observation sheet which is a modification of the partograph sheet. Visual Analog Scale developed by by Perry and Potter (2010) to measure the scale of labor pain in the active phase had been inserted in partograph sheet.

Pretest scores were obtained from the measurement of pain scale before the intervention with VAS at the beginning of the first phase of the active phase (opening $4-7 \mathrm{~cm}$ ) and then the researcher guided the respondent to read the dhikr when the respondent began to feel pain due to contractions until the pain of contraction disappeared during the first phase of the active phase. Posttest scores were measured every 30 minutes during the first phase of the active phase using VAS until the end of the first phase of the active phase (opening $10 \mathrm{~cm}$ ).

Data analysis used was univariate analysis for demographic data variables, maternal age and gestational age data, obstetric data, and pain variables; Hypothesis testing uses repeated measures ANOVA, as well as to control confounding variables with the ANCOVA test.

Every research respondent gets protection by respecting the respondent's rights and holding ethical principles in research.

Volume 8 Issue 2 August 2020
Research respondents signed informed consent before the study was conducted as evidence that they had agreed to participate in the study. Confidentiality is guaranteed by: anonymity in the questionnaire, given a code to mark, store and process data only by the principal investigator. The ethical clearance was approved by the Tangerang District General Hospital ethics committee number 445/06- KEP - RSUTNG.

\section{Results}

An overview of the demographic data of the respondents is presented in table 1 . In general, all respondents were housewives, almost come from etnics Sundanese and with 6 participants getting their secondary education level.

The average age of respondents was at a healthy reproductive age (mean $=25.13$ years, minimum 16 years and a maximum of 33 years). Most of the gestational age respondents have entered term age with an average gestational age of 38 weeks (minimum 28 weeks and a maximum of 43 weeks). Obstetric data shows that seven participants first time mothers (primipara); and all participants had gotten labour induction for the first time. Medical indications for labor induction showed that premature rupture of membran (PROM) is a case that dominates as many as eight participants $(53.30 \%)$, while the type of induction given to respondents is mostly misoprostol or oxytocin each of six participants.

Intensity of pain that was felt by participants before or after the intervention of remembrance was in the range of moderate to severe pain (score 4-10). The difference between the three data sets is the average. Participants before being given the intervention of remembrance felt severe pain (8.27). The result showed that $95 \%$ of labor pain scores before remembrance are in the range of 7.11 to 9.42 . The mean pain score after the dhikr intervention during the first 30 minutes decreased to severe pain (7.47) with a standard deviation of 2.47. It is believed that $95 \%$ of labor pain scores after 30 minutes of dhikr are in the range of 6.09 to 8.84 . However, the mean pain score increased at the end of the first phase of active measurement (7.73). 
Irma Nurbaeti: The Effectiveness of Dhikr to Intensity of Pain during Active Phase

Table 1 Demographic Data $(\mathbf{N}=15)$

\begin{tabular}{lcc}
\hline \multicolumn{1}{c}{ Variable } & $\mathbf{n}$ & \% \\
\hline Etnic & 1 & 6.7 \\
Betawi & 2 & 13.3 \\
Javanesse & 12 & 80.0 \\
Sundanese & & \\
Level of Education & 4 & 26.7 \\
Elementary & 6 & 40.0 \\
Secondary & 4 & 26.7 \\
High School & 1 & 6.7 \\
University & & 100.0 \\
Working status & 15 & 100.0 \\
\hline No work & 15 & \\
Total & & \\
\hline
\end{tabular}

Tabel 2 Distribution Freqiensy of Obstetric Status $(\mathrm{N}=15)$

\begin{tabular}{lcc}
\hline \multicolumn{1}{c}{ Variable } & $\mathbf{n}$ & $\mathbf{\%}$ \\
\hline Parity & 7 & 46.7 \\
Primiparity & 8 & 53.3 \\
Multiparity & & \\
Previous Type of Labour & 7 & 46.7 \\
No & 8 & 53.3 \\
Spontaneuos & & \\
Medical Diagnosis & 8 & 53.3 \\
PROM & 5 & 33.3 \\
Preeclampsia & 2 & 13.3 \\
Postmature & & \\
Type of Induction & 6 & 40.0 \\
Misoprostol & 3 & 20.0 \\
Misoprostol dan oksitosin & 6 & 40.0 \\
Oksitosin & 15 & 100.0 \\
Total & & \\
\hline
\end{tabular}

Table 3 Effectiveness of Dhikr to Intensity of Labour Pain at the Active Phase using Repeated Measures ANOVA

\begin{tabular}{|c|c|c|c|c|c|c|}
\hline \multirow{2}{*}{ Score } & \multirow{2}{*}{$\mathbf{N}$} & \multicolumn{3}{|c|}{ Mean (SD) } & \multirow{2}{*}{$\begin{array}{c}\begin{array}{c}\text { Greenhouse- } \\
\text { Geisser }\end{array} \\
\begin{array}{c}\text { Difference over } \\
\text { time }\end{array} \\
\end{array}$} & \multirow{2}{*}{$\begin{array}{l}\text { Partial Eta- } \\
\text { Squared }\end{array}$} \\
\hline & & Pre & Post 1 & Post 2 & & \\
\hline $\begin{array}{l}\text { Visual Analogue Scale } \\
\text { Score }\end{array}$ & 15 & 8.7 (2.09) & $7.47(2.47)$ & $7.73(2.40)$ & $\begin{array}{c}\mathrm{f}=6.73 \\
\text { P-VALUE }=0.005 \\
\mathrm{DF}=1.92\end{array}$ & 0.325 \\
\hline
\end{tabular}

Table 4 Result of Pairwise Comparison (Bonferroni) Test

\begin{tabular}{lcc}
\hline & Mean difference & P-value \\
\hline VAS before and after intervention 30 minutes & 0.80 & 0.016 \\
VAS before and end of stage I & 0.53 & 0.080 \\
VAS after 30 minutes Intervention and end of stage I & -0.267 & 0.651 \\
\hline 86 & Volume 8 Issue 2 August 2020
\end{tabular}


Irma Nurbaeti: The Effectiveness of Dhikr to Intensity of Pain during Active Phase

Table 5 Covariate Analisis for Confounding

\begin{tabular}{lcccc}
\hline & Df & Mean Square & F & P-value \\
\hline Corrected Model & 2 & 0.167 & 0.166 & 0.849 \\
Intercept & 1 & 0.004 & 0.004 & 0.952 \\
Age & 1 & 0.291 & 0.289 & 0.601 \\
Parity & 1 & 0.255 & 0.254 & 0.624 \\
Error & 12 & 1.006 & & \\
Total & 15 & & & \\
Corrected Total & 14 & & & \\
\hline
\end{tabular}

Table 3 showed that there are at least a pair of meaningful measurements $(\mathrm{F}=6.73$; $\mathrm{p}$-value $=0.005)$. The partial eta squared value of 0.325 indicates that dhikr has a large influence of $32.5 \%$ on changes in the labor pain score. Next Bonferroni post hoc conducted to determine the comparison of effects on the first, second, and third measurements.

Based on Bonferroni's post hoc results in table 4 , the average difference in VAS scores before and after the 30 minutes intervention was 0.8 with a significance value of 0.016 . This shows that remembrance has an influence on pain reduction before and after 30 minutes of intervention. Mean pain scores before and at the end of the first stage decreased by 0.53 . In contrast to the average pain score after 30 minutes of intervention with the end of the first stage increased by 0.267 . Nonetheless, the $p$-value of the two measurement comparisons $>0.05$. Therefore, dhikr effect reduces pain in the early active phase but does not affect the intensity of pain at the end of the first stage

In addition, a covariate analysis test was then performed to determine counfonding factors including age and parity on labor pain intensity. Table 5 shows that maternal age and parity did not affect the decrease in VAS scores. It means that decreasing score of pain did not influenced by age and parity.

\section{Discussion}

Labor pain is an uncomfortable feeling as a manifestation of uterine contractions (Andarmoyo, 2013; Cuningham, 2016). All mothers who give birth must experience labor pain. This is in accordance with the word of God in the QS. Maryam (19): 23

"Then the pain of giving birth to a child forced him (leaning) on the base of the date palm tree, he said:" Oh dear, it would be nice for me to die before this, and I became a meaningless item, again forgotten ".

Labor pain can be caused by physiological and psychological factors (Cuningham, 2016; Leifer, 2015; Meštrović et al., 2015). Psycological factors that can affect labor pain are anxiety and fear in facing labor (Andarmoyo, 2013, Perry et al., 2013). Based on physiological factors, labor pain in the first stage is called visceral pain. Visceral pain is pain that comes from organs. This pain results from uterine muscle hypoxia, accumulation of lactic acid, stretching of the cervix and lower uterine segments and pressure on the pelvic bones. Furthermore, afferent nerve fibers from pain are transmitted to sympathetic nerve fibers to neurotaxis between Toracal 10 to Lumbar 1 (Rici, 2013). Intensity of labour pain can be influenced by induction. Labor pain with induction differs in intensity from spontaneous labor pain. Mothers who have induction labor experience more pain than spontaneous labor (Rahmawati, 2014). Induction of labor can improve maternal and neonatal outcomes. Although induction at term could prevent rare cases of fetal death, all induced women will be exposed to potential discomfort causes of uterine hyperstimulation and more pain compared to mothers without induction (SeijmonsbergenSchermers, 2020). In the first stage labor, generally nurses or midwives provide pain management such as breathing techniques, block pudendus, massage or effleurage to decrease pain in labor. Mardiah (2010) found that $76 \%$ nurses and midwives confered breathing techniques, movement /change of position and massage to eliminir pain in the first stage labor.

The mean maternal pain of labor with induction before dhikr is severe pain (8.27). Pain that is felt by maternity is caused by uterine contractions. The existence of anxiety, 
fear can also increase the pain sensation felt by the mother. This is in accordance with Fear-Tense-Pain Cycle of Dick-Read Theory (1933) in Perry et al., (2013). Mothers can control pain in labour process by reducing pain sensations with relaxation techniques (Cuningham, 2016; Leifer, 2014; Perry et al., 2013). One of the relaxation techniques of meditation for Muslims is remembrance. According to Hudori (2011) religious activities such as remembrance can increase the activity of God Spot, which is the part of the brain that controls religious activities. The existence of activation in God Spot causes impulses to be transmitted to the prefrontal cortex. The prefrontal cortex then passes it to the amygdala. The activated amygdala can stimulate the hypothalamus to activate the parasympathetic nervous system. The parasympathetic nervous system acts as a counter to the sympathetic nervous system whose activity increases due to labor pain (Sherwood, 2012). Parasympathetic nervous system activities can influence the gate control theory on the mechanism of pain in the presence of endorphins secretion by the pituitary gland. Increased endorphin secretion can inhibit Delta-A and C neurons to release substance P. Decreased substance P can close the defense mechanism (the gate), so that the message delivered to the cerebral cortex is not pain but modulation of pain. In general, the activity of the parasympathetic system in addition to pain modulation can also increase a sense of calm, comfort, relax muscles, and make the body more relaxed (Yusuf, 2017).

The benefits of remembrance that can activate the work of the parasympathetic nervous system have also been explained in Qoran:



"(Ie) those who believe and their hearts are at peace in the remembrance of Allah. Remember, only by remembrance of Allah do hearts find satisfaction. "(Surat Ar Ra'du (13): 28).

A Prophet Mohammed said:

"A group of people who dhikr to Allah SWT, must be surrounded by angels, filled with grace, descended calm, mentioned by Allah among the creatures who are on His side" (HR. Muslim).

The above theories and propositions are consistent with the results of this study. The mean pain score after zikr has decreased, both after 30 minutes of zikr and at the end of the first phase of the active phase. The mean pain score before remembrance was 8.27 with a standard deviation of 2.09. After 30 minutes of remembrance, the mean pain decreased to 7.47. The mean pain score at the end of the first stage when compared to before the dhikr also decreased by 0.53 , so the mean pain score was 7.73 .

The results of this study indicate that there is a pair of meaningful measurements and remembrance had a major influence on changes in labor pain scores in the active phase of the first phase by $32.5 \%$. Labor pain can be influenced by several factors. According to previous researchs, factors affected labor pain were the age of the mother and parity (Mestrovic et al., 2015; Shrestha et al., 2013; Tampubulon, 2015). The participants in this study were in the age range 16-33 years with a mean of 25.13. Based on statistical results using Test ANCOVA, age does not affect the decrease in labor pain score ( $p$-value $=$ 0.601 ). This means that mothers in all age ranges are the same feel pain at labor by induction. This is different from spontaneous delivery, labor pain felt by the mother is greatly affected by age (Maghfiroh, 2012; Shrestha et al., 2013; Tampubulon, 2015). Based on the readiness of the mother to give birth, the age is categorized into low-risk (2035 years $)$ and high-risk age $(<20$ years or $>$ 35 years). Shrestha et al. (2013) explained that mothers under the age of 20 experience severe pain more than the older mother. This may happen because of a young mother psychologically have not enough emotion and psychology adults who can affect their acceptance of labor pain (Cunningham, 2016). Another factor that most influences to labor pain is parity. This result similar with Maghfiroh (2012) that parity status and previous experience of labor pain can be affected the pain of first stage labor in spontaneous labor. Parity status is related to the experience of dealing with pain previous delivery. Multipara is considered to have had deep experience faced previous labor pains, 
Irma Nurbaeti: The Effectiveness of Dhikr to Intensity of Pain during Active Phase

resulting in on delivery then she is better able to control the pain of her labor than primipara. Furthermore, based on the post hoc analysis Bonferroni showed that the dhikr affected the reduction in pain in the measurement after 30 minutes of intervention $(p$-value $=0.016$ ) at the opening of $4-7 \mathrm{~cm}$. The results of this study are in line with the results of research by Fajriah (2013) and Nurbaeti (2015) that prove the influence of dhikr on the reduction of labor pain in the active phase. However, there are differences with the results of previous studies conducted by Nurbaeti (2015). In previous studies, dhikr had a large influence of $66.5 \%$ on the reduction in labor pain, while in this study the influence of dhikr was $32.5 \%$. The large difference in influence can be due to differences in research subjects. Subjects from previous studies were mothers with normal deliveries, while the subjects in this study were induction mothers who had greater pain intensity.

The measurement of pain is then performed at the end of the active phase I ie at $10 \mathrm{~cm}$ opening with a mean pain score of 7.73 , and it is believed that $95 \%$ of the pain score at the end of the active phase of the active phase of induction labor is 6.4 to 9.06. Bonferroni's post hoc analysis showed the remembrance did not have an effect on changes in pain scores at the end of the first phase of active measurement $(p=0.08)$. Non significant in the end of stage I causes mothers in transition to complete cervical ripening feel lost control, unable to relax, are easily offended because the contractions are felt to be very strong, more display and more painful, and the mother has focused on the second stage of labor. Thus, Nurse midwives should manage to control pain from the beginning to end of first stage labour (Karlsdottir et al., 2014).

\section{Conclusion}

Dhikr significantly effected to lower intensity of pain at early stage I among inducing mothers but have no effect in end of stage I labour after controlled by age and parity. Dhikr can use to control pain in early first stage I labour both for primiparaous or multiparaous. This study had limitation of recruited in small group with one group for future research we suggest to conduct quasy experiment with two group control and intervention.

\section{References}

Andarmoyo, Sulistyo, \& Suharti. (2013). Persalinan tanpa nyeri persalinan berlebihan. (Labor without excessive labor pain). Ar-Ruzz Media.

Cunningham, G.F. (2016). Obstetri williams (Edisi 23, Volume 2). EGC.

Fajria, L. (2014). Pengaruh Terapi Relaksasi Zikir Terhadap Intensitas Nyeri Persalinan Kala I Fase Aktif pada Ibu Primigravida. (The effect of dhikr relaxation therapy on the intensity of labor pain in the active phase I in primigravida patients). Ners Jurnal Keperawatan, 10(2), 10-19. http://dx.doi. org/10.25077/njk.10.2.\%p.2014

Goodwin, T.M. (2010). Management of common problems in obstetrics and gynecology (5th Ed.). Wiley-Blackwell.

Hudori. (2011). Relasi kecerdasan spiritual dan pencarian jejak Tuhan. Soul, 1(2).

Karlsdottir, S.I., Halldorsdottir, S., Lundgren, I. (2014). The third paradigm in labour pain preparation and management: The childbearing woman's paradigm. Scand $J$ Caring Sci., 28(2), 315-327. https://doi.org/ $10.1111 /$ scs. 12061

Leifer, G. (2015). Introduction to maternity and pediatric nursing (7th Ed.). Missouri: Elsevier.

Maghfiroh, A. (2012). Faktor-faktor yang berhubungan dengan nyeri persalinan kala I fase aktif di Ruang Bersalin RSU Kabupaten Tangerang. [Bachelor's thesis, UIN Syarif Hidayatullah]. Repository UIN Jakarta. Retrieved January 12, 2020 from https://repository.uinjkt.ac.id/dspace/ handle/123456789/25501

Manning, P. (2013). Drugs and popular culture. Willan Publisher. 
Mardiah, W.(2010). Penanganan nyeri yang dilakukan oleh perawat dan bidan pada ibu bersalin di Puskesmas Pagarsih dan Puskesmas Garuda Kodya Bandung. (Pain management carried out by nurses and midwives in women giving birth at Pagarsih Health Center and Garuda Health Center in Bandung City.) Majalah Keperawatan Unpad, 12 (1). Retrieved January 9, 2020, from https://jurnal.unpad.ac.id/mku/article/ view/33

Mestrović, A. H., Bilić, M., Loncar, L. B., Micković, V., \& Loncar, Z. (2015). Psychological Factors in Experience of Pain During Childbirth. Collegium antropologicum, 39(3), 557-565. Retrieved January 12, 2020, from https://www.ncbi. nlm.nih.Gov/Pubmed/26898050

Nuraeni, A., Ibrahim, K., Rizmadewi, H. (2013). Makna Spiritualitas pada Klien dengan Sindroma Akut Koroner. (The meaning of spirituality in clients with acute coronary syndrome). Jurnal Keperawatan Padjadjaran, 1(2), 79-87. https://doi. org/10.24198/jkp.v1i2.55

Nurbaeti, I. (2015). Efektifitas dzikrullah terhadap penurunan kecemasan dan nyeri persalinan kala I fase aktif ibu primigravida. (The effectiveness of dhikrullah on reducing anxiety and labor pain in the first stage of the active phase of primigravida mothers). Jurnal Ners, 10, 30-37.

Perry, S.E., Hockenberry, M.J., \& Lowdermilk, D.L. (2013). Maternal child nursing care (4th Ed.). Elsevier.

Potter \& Perry. (2010). Buku ajar fundamental keperawatan. EGC.

Rahmawati, D. (2014). Perbandingan nyeri persalinan spontan dan nyeri induksi persalinan. [Master's thesis, University of Indonesi]. Universitas Indonesia. Retrieved January 3, 2020, from https://lib. ui.ac.id/file?file=digital/2016-10/124741Desrinah\%20Harahap.pdf

Rici, S.S., \& Kyle, T. (2013). Maternity and pediatric nursing. Philadephia: Lippincott William And Wilkens.
Saragih, R. (2017). Pengaruh dukungan suami dan tingkat kecemasan ibu primigravida terhadap lama kala I persalinan sopntan di Klinik Bersalin Swasta Wilayah Kerja Puskesmas Tanah Tinggi Kota Binjai Tahun 2014. Jurnal Ilmiah Kohesi, 1.

Seijmonsbergen-Schermers, AE., Scherjon, S., and Jonge, A. (2020). Induction of labour should be offered to all women at term. BJOG: An International Journal of Obstetrics \& Gynaecology, 127(6), 777-777. https://doi. org/10.1111/1471-0528.16159

Sherwood, L. (2012). Fisiologi manusia dari sel ke sistem. (Human physiology from cell to system). EGC.

Shrestha, I., Pradhan, N., \& Sharma, J. (2013). Factors influencing perception of labor pain among parturient women at Tribhuvan University Teaching Hospital. Nepal Journal of Obstetrics and Gynaecology, 8(1), 26-30. https://doi.org/10.3126/Njog.V8i1.8857

Sumaryani, S \& Nurasa, (2010). Pengaruh Pembacaan Dzikir Pada Ibu Melahirkan Terhadap Tingkat Nyeri Intranatal Di Rumah Bersalin Fajar Yogyakarta. (The effect of reading dhikr on mothers giving birth to the level of intranatal pain at Fajar Maternity Home Yogyakarta). Jurnal Keperawatan, 1(1), 39-44.

Tampubolon, E.A. (2015). Nyeri dan faktor faktor yang mempengaruhi nyeri persalinan pada kala I di Klinik Bersalin Delima Medan Belawan Tahun 2014. [Bachelor's thesis, Universitas Sumatera Utara] USU Repository. Retrieved January 12, 2020, from http:// repository.usu.ac.id/handle/123456789/4424

Viteri, O. A., \& Sibai, B. M. (2018). Challenges and Limitations of Clinical Trials on Labor Induction: A Review of the Literature. AJP reports, 8(4), e365-e378. https://doi.org/10.1055/s-0038-1676577

Yusuf, D. (2017). Kebutuhan spiritual: Konsep dan aplikasi dalam asuhan keperawatan. (Spiritual needs: Concepts and applications in nursing care). Mitra Wacana Media. 